\title{
Semi-dwarf barley (Hordeum vulgare L.) brh2 and ari-I mutants are deficient in a U-box E3 ubiquitin ligase
}

\author{
Ilka Braumann ${ }^{1} \cdot$ Wojciech Urban ${ }^{1} \cdot$ Aileen Preuß ${ }^{1} \cdot$ Christoph Dockter $^{1} \cdot$ Shakhira Zakhrabekova $^{2} \cdot$ Mats Hansson $^{2} \mathbb{C}$
}

Received: 5 December 2017 / Accepted: 2 July 2018 / Published online: 7 July 2018

(c) The Author(s) 2018

\begin{abstract}
Lodging is the process where crop plants fall over and lie on the ground due to strong winds and heavy precipitation. This problem reduces yield and increases the risk of fungal infections and pre-harvest germination. In order to avoid lodging, plant breeders utilize short-culm mutants, which often have a robust culm that can support the weight of a heavy spike. In barley (Hordeum vulgare L.), thousands of short-culm mutants have been isolated in breeding programs around the world. Our long-term goal is to reveal the genetic network underlying culm length, with the objective to provide an enlarged repertoire of genes and alleles suitable for future breeding of lodging resistant barley. In the present work we studied a group of allelic brh2 and ari-l mutants, which have a relatively strong semi-dwarf phenotype and are phenotypically similar to previously identified mutants deficient in brassinosteroid signalling or metabolism. The Brh2 gene is located in the centromeric region of chromosome $4 \mathrm{H}$ and we applied a candidate gene approach to identify the gene. Brh2 is orthologous to TUD1 in rice (Orysa sativa L.), which encodes a U-box E3 ubiquitin ligase. We identified one missense mutation, one nonsense mutation and four deletions of the complete Brh2 gene. The mutants could respond to exogenously applied brassinolide, which suggests that the apparent brassinosteroid deficient phenotype of barley brh 2 and ari-l mutants is related to brassinosteroid metabolism rather than signalling.
\end{abstract}

Keywords Ari-l $\cdot$ Brh2 $\cdot$ Heterotrimeric G protein $\cdot$ Lodging $\cdot$ TUD1

$\begin{array}{ll}\text { Abbreviations } \\ \text { ari } & \text { Breviaristatum } \\ \text { brh } & \text { Brachytic } \\ \text { ert } & \text { Erectoides } \\ \text { GDP } & \text { Guanosine-5'-diphosphate }\end{array}$

Mats Hansson

mats.hansson@biol.lu.se

Ilka Braumann

ilka.braumann@carlsberg.com

Wojciech Urban

wojciech.jan.urban@uni-hamburg.de

Aileen Preuß

aileen.preuss@hotmail.de

Christoph Dockter

christoph.dockter@carlsberg.com

Shakhira Zakhrabekova

shakhira.zakhrabekova@biol.lu.se

1 Carlsberg Research Laboratory, J. C. Jacobsens Gade 4, 1799 Copenhagen V, Denmark

2 Department of Biology, Lund University, Sölvegatan 35, 22362 Lund, Sweden
GTP Guanosine-5'-triphosphate

RGS Regulator-of-G-protein-signalling

sdw Semi-dwarf

uzu Semi-brachytic

\section{Introduction}

The introduction of nitrogen fertilizers has had an enormous impact on agricultural production but it also brought a challenge to the plant breeders since the culms of the cereal crop cultivars could not support the heavy spikes of fertilized plants and therefore the plants were prone to lodging. The use of growth regulators has been one approach to combat the problem with lodging. Another approach has been to explore semi-dwarf mutants, which are often more resistant to lodging due to their short and sturdy culm. Uzu-type barley (Hordeum vulgare L.) was one of the first short-culm mutants to be used (Takahashi 1955). In the 1930 s, $70 \%$ of the barley grown in Japan was of uzu-type and 70 years later the uzul.a allele had been introduced in almost all Japanese hull-less barley cultivars (Saisho et al. 
2004). It is now known that uzul.a has a point mutation in the HvBRII gene encoding the brassinosteroid receptor (Chono et al. 2003; Dockter et al. 2014). While uzul.a is a spontaneous mutation isolated in Japanese land races, ert$k .32$ was induced by X-ray treatment of the Swedish cultivar Bonus in 1947. Mutant ert-k.32 was released in 1958 as the cultivar Pallas, which was one of the first cereal crop cultivars developed from induced mutants. The Ert-k gene has still not been identified at DNA level (Skov Kristensen et al. 2016). Another very successful short-culm cultivar has been the Scottish malting cultivar Golden Promise, which was isolated after $\gamma$-ray mutagenesis of cultivar Maythorpe in 1956 (Ahloowalia et al. 2004; Foster 2001; Wendt et al. 2016). The most successful locus has however been $S d w 1$ (HvGA20ox2) encoding gibberellin 20-oxidase (Xu et al. 2017). The first reported allele was $s d w 1 . c$ (originally named denso), a spontaneous mutation found in the cultivar Abed Denso from the Abed breeding station in Denmark (Haahr and von Wettstein 1976; Vestergaard et al. 1949). The $s d w 1 . d$ allele was obtained by X-ray treatment of the cultivar Valticky and released as the cultivar Diamant in 1965 (Bouma 1967; Haahr and von Wettstein 1976). The $s d w 1 . d$ allele is widespread in many modern barley elite cultivars grown today (Xu et al. 2017). The success of $s d w 1 . d$ is probably due to less apparent pleiotropic effects of the mutation, since short-culm mutants often have unwanted traits like short roots, small and rounded kernels and short spikes. However, also $s d w 1$ mutant alleles are associated with negative pleotropic effects on yield and potentially malting quality (Hellewell et al. 2000). Lodging can be expected to become an increasing problem since global climate warming is supposed to increase the number of days with strong winds and thunderstorms (Porter and Semenov 2005). In the view of increased problems with lodging and that fact that $s d w 1 . d$ tend to dominate the short-culm barley elite cultivars (Xu et al. 2017), it is of relevance to identify and characterize the gene network regulating plant architecture and thereby lodging resistance, which can be mobilized in future plant-breeding activities.

The short-culm alleles used in the today's barley elite cultivars are the result of massive efforts in mutant breeding that has generated thousands of short-culm mutants of which many are stored at various seedbanks. These mutants can be explored to dissect the molecular mechanisms regulating plant architecture. The mutants are mainly found in the mutant groups named brachytic (brh), semi-brachytic (uzu), erectoides (ert), breviaristatum (ari), dense spike (dsp), curly dwarf (cud), semi-dwarf (sdw) and slender dwarf(sld). Various mutations from these groups have been described at DNA level and associated with nine genes encoding proteins, which obviously are regulators of plant architecture (Table 1). More than 20 mutants are deficient in brassinosteroid signalling or biosynthesis. We have previously described an ideotype of brassinosteroid mutants in barley based on uzul.a causing a His857Arg modification in the kinase domain of the brassinosteroid receptor (Dockter et al. 2014). This ideotype helped us to identify three other genes encoding key enzymes of the brassinosteroid biosynthetic pathway; HvBRD1, HvCPD, HvDIM (Dockter et al. 2014). Other mutants showed strong similarities to the brassinosteroid ideotype but turned out to be deficient in $H v D 1$ and $H v D E P 1$ encoding the $\alpha$ - and $\gamma$-subunit, respectively, of a heterotrimeric G protein (Table 1) (Braumann et al. 2017; Wendt et al. 2016). In addition to an $\alpha$ - and a $\gamma$-subunit, heterotrimeric $\mathrm{G}$ proteins are also composed of a $\beta$-subunit (Assmann 2002; Oki et al. 2009). Heterotrimeric G proteins are mostly known from mammalian systems where there are several genes encoding $\alpha(G \alpha), \beta(G \beta)$ and $\gamma(G \gamma)$ subunits. In mammalian systems, binding of a ligand to the G-proteincoupled receptor causes a rapid exchange of GDP to GTP bound by the $\mathrm{G} \alpha$ subunit, which promotes a dissociation of activated G $\alpha$-GTP from the G $\beta \gamma$ heterodimer (Temple and Jones 2007). Activated G $\alpha$-GTP and/or G $\beta \gamma$ interact with the effector proteins. A different system for G-protein signalling is found in plants. There is only one $G \alpha$, one $G \beta$ and three $\mathrm{G} \gamma$ encoding genes in Arabidopsis, and one $\mathrm{G} \alpha$, one $\mathrm{G} \beta$ and four $\mathrm{G} \gamma$ genes in rice (Oryza sativa $\mathrm{L}$.) (Kato et al. 2004; Temple and Jones 2007; Utsunomiya et al. 2011). The Arabidopsis G $\alpha$ subunit spontaneously binds GTP in vitro (Johnston et al. 2007) but its ability to stimulate effector molecules is inhibited by its association to a membrane bound Regulator-of-G-protein-signalling (RGS) protein (Urano et al. 2013). Upon binding of a ligand to the RGS protein, the G $\alpha$-GTP subunit is released and can interact with effector molecules.

In the present study we focus on mutants in the barley $B r h 2$ locus since they all show strong similarity to the brassinosteroid deficient ideotype. Mutants in the Brh2 locus were isolated more than 50 years ago as short-culm or short-awn mutants (Kucera et al. 1975; Tsuchiya 1962) and Brh2 is located in the centromeric region of chromosome 4H (Druka et al. 2011). We identify Brh2 as an orthologue to rice TUDI encoding a U-box E3 ubiquitin ligase and describe seven allelic barley mutants at the DNA level. In rice, the TUDI encoded U-box E3 ubiquitin ligase has been shown to interact with the $D l$ encoded $\alpha$-subunit of the heterotrimeric G protein (Hu et al. 2013).

\section{Materials and methods}

\section{Plant materials and growth conditions}

Barley (Hordeum vulgare L.) cultivars Bonus, Foma, Bowman, Kristina, Svanhals as well as mutants brh2.b, ari-l.3, ari-l.132, ari-l.135, ari-l.145, ari-l.214, ari-l.237, ari-l.257, 
Table 1 Overview of identified barley short-culm genes and their corresponding mutants

\begin{tabular}{|c|c|c|c|c|}
\hline Gene name & Mutants & Gene product & Pathway & References \\
\hline$H v G A 20 o x 2$ & $s d w 1 . a, s d w 1 . c, s d w 1 . d$ & Gibberellin 20-oxidase & Gibberellin biosynthesis & Xu et al. (2017) \\
\hline$H v B R I 1$ & $\begin{array}{l}\text { ert-ii.79, uzu1.a, uzu1.b, } \\
\text { uzu1.c, uzu1.256, иzu1.297, } \\
\text { uzu1.301 }\end{array}$ & Brassinosteroid receptor & Brassinosteroid signaling & $\begin{array}{l}\text { Chono et al. (2003), Dockter } \\
\text { et al. (2014), Gruszka et al. } \\
\text { (2011) }\end{array}$ \\
\hline$H v B R D$ & $\begin{array}{l}\text { ari-u.245, ari-u.304, brh3.g, } \\
\quad \text { brh3.h, brh3.i, brh3.y, ert- } \\
\quad t .437\end{array}$ & Brassinosteroid-6-oxidase & Brassinosteroid biosynthesis & Dockter et al. (2014) \\
\hline$H v C P D$ & brh13.p, brh18.ac & $\begin{array}{l}\text { C-23 } \alpha \text {-hydroxylase cytochrome } \\
\text { P450 }\end{array}$ & Brassinosteroid biosynthesis & Dockter et al. (2014) \\
\hline$H v D I M$ & $\begin{array}{l}\text { ari-o. } 40, \text { ari-o. } 43, \text { ari-o. } 143 \text {, } \\
\text { brh.af, brh14.g, brh16.v, ert- } \\
\text { u.56, ert-zd.159 }\end{array}$ & $\Delta^{5}$-sterol- $\Delta^{24}$-reductase & Brassinosteroid biosynthesis & Dockter et al. (2014) \\
\hline$H v A P 2$ & $\begin{array}{l}\text { Ert-r.52, Ert-r.67, Ert-r.329, } \\
\text { Ert-r.453, Zeo1.a, Zeo1.b, } \\
\text { Zeo1.c, Zeo2.c, Zeo2.d, } \\
\text { Zeo2.h, Zeo2.j, Zeo2.av, } \\
\text { Zeo2.ax }\end{array}$ & $\begin{array}{l}\text { Transcription factor contain- } \\
\text { ing two AP2 DNA-binding } \\
\text { domains and a miR172- } \\
\text { binding site }\end{array}$ & Unknown & Houston et al. (2013) \\
\hline HvERECTA & $\begin{array}{l}\text { ert-m.34, ert-m.35, ert-m. } 40, \\
\text { ert-m. } 42 \text {, ert-m. } 54 \text {, ert-m. } 64 \text {, } \\
\text { ert-m. } 87 \text {, ert-m. } 107 \text {, ert- } \\
\text { m. } 115 \text {, ert-m. } 130, \text { ert-m. } 144 \text {, } \\
\text { ert-m. } 168, \text { ert-m. } 169 \text {, ert- } \\
\text { m.330, ert-m.363, ert-m. } 426\end{array}$ & $\begin{array}{l}\text { Leucine-rich repeat receptor- } \\
\text { like kinase }\end{array}$ & Unknown & Zakhrabekova et al. (2015) \\
\hline$H v D 1$ & $\begin{array}{l}\text { ari-i.38, ari-m.12, ari-m.28, } \\
\text { ari-m.141, ari-m.177, ari- } \\
\text { m.251, ari-m.269, brh1.a, } \\
\text { brh1.aa, brh1.ae, brh1.c, } \\
\text { brh1.e, brh1.f, brh1.t, brh1.x }\end{array}$ & $\begin{array}{l}\text { Heterotrimeric G protein } \\
\alpha \text {-subunit }\end{array}$ & Unknown & $\begin{array}{l}\text { Braumann et al. (2017), Ito et al. } \\
\text { (2017) }\end{array}$ \\
\hline$H v D E P 1$ & $\begin{array}{l}\text { ari-e.1, ari-e.30, ari-e.39, ari- } \\
\text { e.119, ari-e.156, ari-e.166, } \\
\text { ari-e.GP }\end{array}$ & $\begin{array}{l}\text { Heterotrimeric G protein } \\
\gamma \text {-subunit }\end{array}$ & Unknown & Wendt et al. (2016) \\
\hline
\end{tabular}

Table 2 Description of barley brh2 and ari-l mutants

\begin{tabular}{|c|c|c|c|c|}
\hline Mutant & Mother cultivar & Mutagen & Year of isolation & Accession number \\
\hline$b r h 2 . b$ & Svanhals & $\mathrm{X}$-rays & 1962 or earlier & GSHO 573 \\
\hline ari-l.3 & Bonus & $\mathrm{X}$-rays & 1955 & NGB 115848 \\
\hline ari-l.132 & Foma & Ethylene imine & 1960 & NGB 115942 \\
\hline ari-l.135 & Foma & Ethyl methanesulfonate & 1960 & NGB 115945 \\
\hline ari-l.145 & Foma & Ethyl methanesulfonate & 1960 & NGB 115956 \\
\hline ari-l.214 & Foma & Ethyl methanesulfonate & 1965 & NGB 116023 \\
\hline ari-l.237 & Foma & $\begin{array}{l}N \text {-ethyl- } N \text {-nitroso- } N^{\prime}- \\
\text { nitroguanidine }\end{array}$ & 1966 & NGB 116047 \\
\hline ari-l.257 & Kristina & Ethyl methanesulfonate & 1968 & NGB 116066 \\
\hline BW050 (ari-l.3) & $\begin{array}{l}\text { Near-isogenic line } \\
\text { of ari-l.3 created } \\
\text { in cultivar Bow- } \\
\text { man }\end{array}$ & & & NGB 20458 \\
\hline BW090 (brh2.b) & $\begin{array}{l}\text { Near-isogenic line } \\
\text { of } b r h 2 . b \text { created } \\
\text { in cultivar Bow- } \\
\text { man }\end{array}$ & & & NGB 20496 \\
\hline
\end{tabular}


BW050 (ari-l.3 near-isogenic line in cultivar Bowman background) and BW090 (brh2.b) (Table 2) were grown in greenhouse at $18{ }^{\circ} \mathrm{C}$ under a cycle of $16-\mathrm{h}$ light/8-h dark. Light intensity was set to a photon flux of $300 \mu \mathrm{mol} \mathrm{m} \mathrm{m}^{-2} \mathrm{~s}^{-1}$. The plant material was obtained from the Nordic Genetic Resource Center (Alnarp, Sweden; http://www.nordgen.org) except for the original $b r h 2 . b$ mutant which was obtained from the National Small Grains Collection (https://www. ars.usda.gov/pacific-west-area/aberdeen-id/small-grain s-and-potato-germplasm-research/docs/national-small-grain s-collection/).

\section{DNA techniques}

Genomic DNA was isolated from leaf segments by using the REDExtract-N-Amp Plant PCR Kit (Sigma-Aldrich). Leaf segments of $0.5 \mathrm{~cm}$ were transferred to 96 -well plates for genomic DNA extraction. Then, $40 \mu \mathrm{l}$ of extraction solution was added to the plant samples and incubated at $95{ }^{\circ} \mathrm{C}$ for $10 \mathrm{~min}$, followed by addition of $40 \mu \mathrm{l}$ of dilution solution. PCR amplifications were performed according to the manufacturer's protocol by using REDExtract-NAmp PCR ReadyMix, which contains JumpStart Taq antibody for specific hot-start amplification. For $25 \mu \mathrm{l} \mathrm{PCR}$ reactions, $10 \mu \mathrm{l}$ REDExtract-N-Amp PCR ReadyMix was mixed with $10.5 \mu \mathrm{l}$ water, $1.25 \mu \mathrm{l}$ of each forward and reverse primers $(10 \mu \mathrm{M})$ and $2 \mu \mathrm{l}$ of genomic DNA. Primers were designed to generate four overlapping fragments of barley Brh2 (Table 3). The primers were based on the sequence of bowman_contig_65106 containing the gene MLOC_79322 (International Barley Genome Sequencing et al. 2012), which we now identified as the Brh2 gene. PCRs were performed for 37 cycles (initial denaturation at $94{ }^{\circ} \mathrm{C} / 2$ min followed by 37 cycles of $94{ }^{\circ} \mathrm{C} / 45 \mathrm{~s}$, $61{ }^{\circ} \mathrm{C} / 45 \mathrm{~s}$, and $72{ }^{\circ} \mathrm{C} / 40 \mathrm{~s}$ for extension, with a final extension step of $72{ }^{\circ} \mathrm{C} / 5 \mathrm{~min}$ ). Amplified PCR products were purified for sequencing using the Nucleospin Gel and PCR Clean-Up kit (Macherey-Nagel GmbH \&
Co. KG, Düren, Germany) following the manufacturer's instruction. DNA sequencing was performed by StarSEQ $\mathrm{GmbH}$, Mainz, Germany using the primers described in Table 3. PCR fragments, instead of PCR fragments cloned into plasmid vectors, were sequenced in order to avoid fidelity problems of the polymerase. Each found mutation was covered by two overlapping PCR fragments amplified from different pairs of PCR primers. DNA and protein sequences were analyzed with BioEdit (http://www.mbio. ncsu.edu/bioedit/bioedit.html), the NCBI BLAST tool (http://blast.ncbi.nlm.nih.gov/Blast.cgi), the Phytozome BLAST tool (http://www.phytozome.net), the IPK Barley BLAST Server (http://webblast.ipk-gatersleben.de/barley_ $\mathrm{ibsc/)}$ and BARLEX - The Barley Genome Explorer (https ://apex.ipk-gatersleben.de/apex/f?p=284:10::::::). Multiple polypeptide sequence alignments were performed by the Multiple Sequence Alignment program "ClustalW" http:// www.ebi.ac.uk/Tools/msa/clustalw2/.

\section{Leaf-unrolling and leaf lamina inclination bioassays}

In leaf-unrolling bioassays the plants were grown in darkness for 9 days at $16{ }^{\circ} \mathrm{C}$. A $2 \mathrm{~cm}$ tightly rolled leaf segment was cut from each etiolated seedling and immersed in water or in a solution containing $200 \mathrm{nM}$ 24-epi-brassinolide (Sigma-Aldrich). The width of the leaf segment was measured at 0 and $72 \mathrm{~h}$. Also the full width (forced open) of the leaf segment was measured. All operations were performed in the dark or under green dim light (Dockter et al. 2014; Honda et al. 2003).

In leaf lamina inclination bioassays (Dockter et al. 2014; Fujioka et al. 1998; Hong et al. 2003), $1 \mu \mathrm{l}$ of $2 \mathrm{mg} \mathrm{ml}^{-1}$ 24-epi-brassinolide solved in $96 \%$ (v/v) ethanol was added to the tip of barley seedlings just emerging from germination in vermiculite. Ethanol was added to control plants. The angle between the first leaf and the second leaf was observed when the second leaf obtained a similar size as the first leaf.
Table 3 Description of oligonucleotides used as primers for amplification and sequencing of $B r h 2$

\begin{tabular}{|c|c|c|c|c|}
\hline Primer & Sequence & Combined with primer & $\begin{array}{l}\text { Length of } \\
\text { fragment }\end{array}$ & $\begin{array}{l}\text { Position of } \\
\text { fragment in } \\
\text { sequence }\end{array}$ \\
\hline WU1For & AGGTAGCCGCAGAACCCCAG & WU1Rev & 834 & $27-860$ \\
\hline WU1Rev & GAGGTCAGCAACGACACGCC & & & \\
\hline WU3For & GCGTGTCGTTGCTGACCTCG & WU3Rev & 612 & $842-1453$ \\
\hline WU3Rev & ACTCCTCGGGCACCATCCTG & & & \\
\hline WU5For & TCATCTGCCCGATCTCCCTG & WU6Rev & 546 & $452-997$ \\
\hline WU6Rev & TGAGCATGTCCACCACGAGG & & & \\
\hline WU9For & TGAAGGATTGCCCGAGGACG & WU10Rev & 557 & $1334-1890$ \\
\hline WU10Rev & GGTGGTGCTTATGCTGCCGC & & & \\
\hline
\end{tabular}

The position of fragment refers to the sequence in Fig. 4 


\section{Results}

Barley $b r h 2 . b$ was isolated after X-ray treatment of the cultivar Svanhals (Tsuchiya 1962). It was later shown to be allelic to ari-l.3 (Dahleen et al. 2005), which is one of seven allelic ari-l mutants (Kucera et al. 1975) (http://www.nordg en.org/bgs). The other six ari-l mutant lines are named aril.132, ari-l.135, ari-l.145, ari-l.214, ari-l.237 and ari-l.257 (Table 2). Near-isogenic lines have been created for $b r h 2 . b$ and ari-l.3 through six recurrent backcrosses to the cultivar Bowman (Druka et al. 2011). The near-isogenic lines are named BW090 and BW050, respectively.

Barley brh2 and ari-l mutants show a relatively strong semi-dwarf phenotype (Fig. 1; Tables 4, 5). Plant height and awn length are reduced to approximately $2 / 3$ and $1 / 4$ normal length, respectively. In addition, grain yield is lower since especially thousand-grain-weight is reduced (Table 4). Notably, brh2 and ari-l mutants show many of the brassinosteroid-deficient characteristics previously described in barley mutants deficient in brassinosteroid signalling or biosynthesis (Dockter et al. 2014). This includes the semidwarf appearance, undulated leaf margins, an erect growth habit and short awns (Fig. 1). Due to the brassinosteroiddeficient characters we performed leaf-unrolling bioassays (Dockter et al. 2014; Honda et al. 2003) with BW050 (aril.3), BW090 (brh2.b) and Bowman. In this assay etiolated leaf segments are immersed in $200 \mathrm{nM}$ brassinolide. Leaves of brassinosteroid receptor mutants are expected to remain rolled, whereas plants with an intact receptor open up, i.e. unrolling. The present experiment showed a clear unrolling of BW050 (ari-l.3), BW090 (brh2.b) and Bowman (Fig. 2). We also performed leaf lamina inclination assays (Dockter et al. 2014; Fujioka et al. 1998; Hong et al. 2003). In these assays brassinolide solubilized in ethanol, or just ethanol as negative control, is added to the tip of a newly germinating barley seedling. After approximately 2 weeks the barley plant has developed two leaves. In seedlings treated with brassinolide the first and second leaves become well separated from each other. In contrast, the first and second leaves remain close together in plants treated with ethanol or in brassinosteroid receptor mutants treated with brassinolide (Dockter et al. 2014). We observed that BW050 (ari-l.3), BW090 (brh2.b) and Bowman show a clear response to exogenous brassinolide in a leaf lamina inclination assay (Fig. 3). Thus, brh2 and ari-l mutants are sensitive to
Fig. 1 Phenotypes of barley ari-l.3 and brh $2 . b$ mutant lines. a The near-isogenic line BW050 (ari-l.3) to the right compared to Bowman on the left. b BW090 (brh2.b) to the right compared to Bowman on the left. c-e Leaves of BW050 (d) and BW090 (e) have undulating leaf margins and are more upright than leaves of Bowman (c). $\mathbf{f}-\mathbf{h}$ Awns of BW050 (g) and BW090 (h) are much shorter compared to awns of Bowman (f)

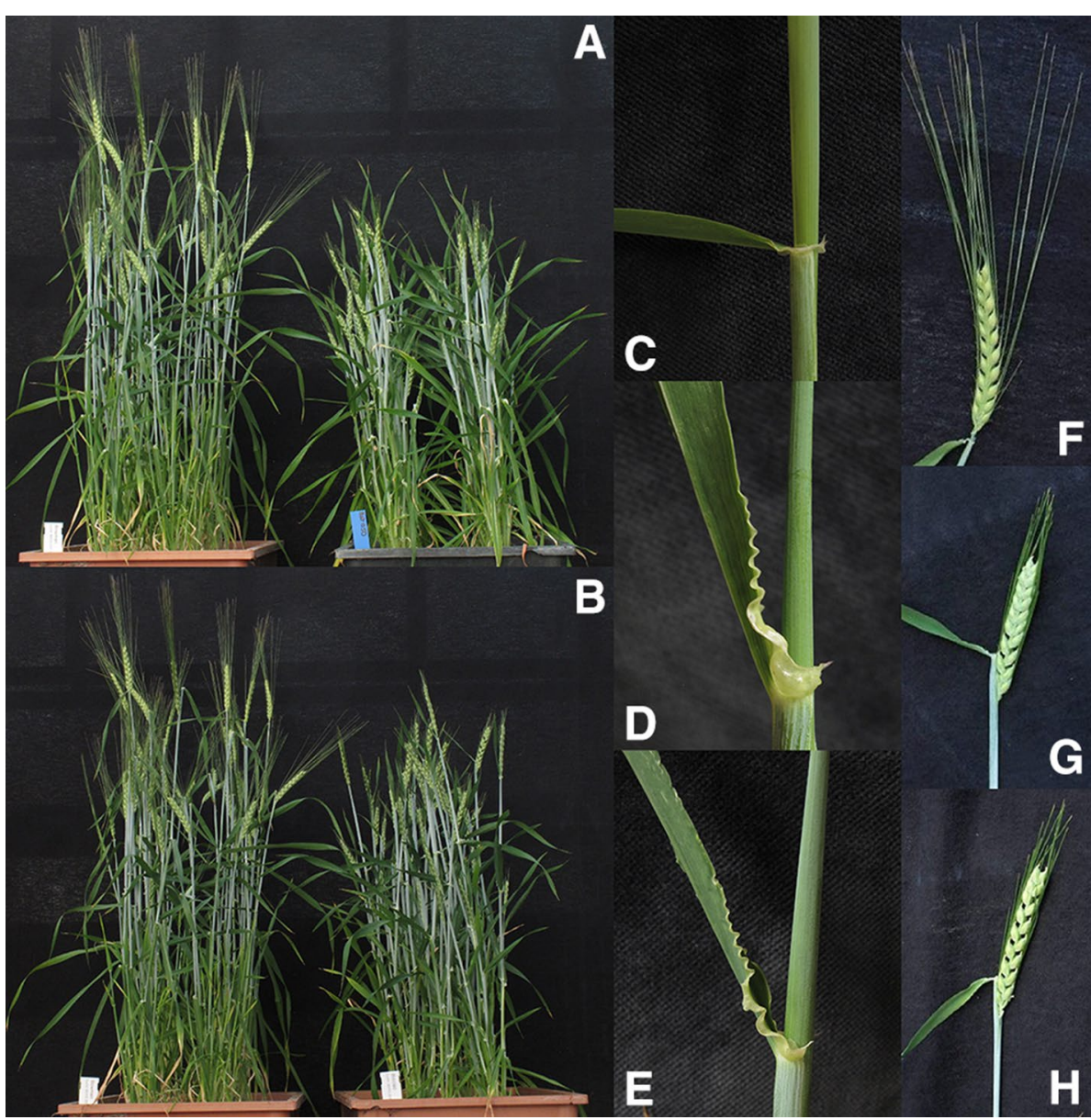




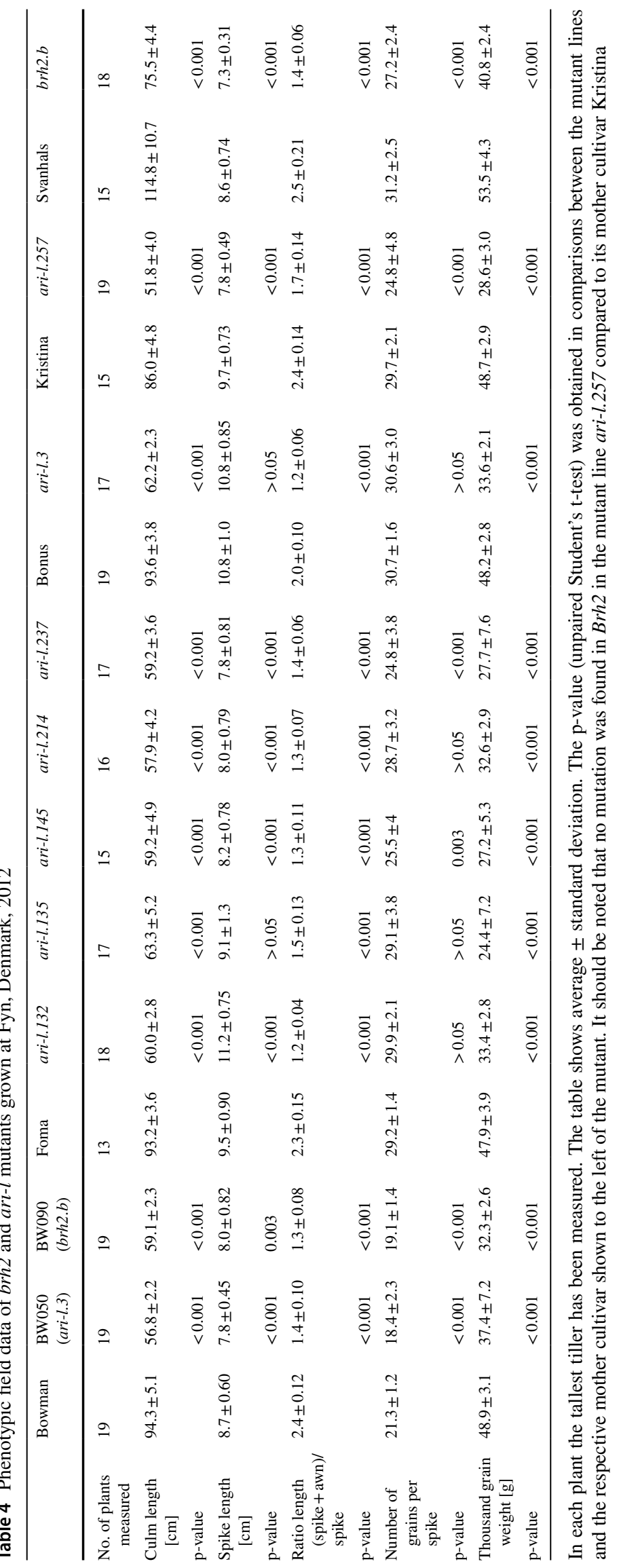


Table 5 Phenotypic data of $b r h 2$ and ari-l mutants grown in $2 \mathrm{~L}$ pots in greenhouse at Lund University, Sweden, 2015

\begin{tabular}{|c|c|c|c|c|c|c|c|}
\hline & Bowman & BW050 (ari-l.3) & BW090 (brh2.b) & Bonus & ari-l.3 & Svanhals & $b r h 2 . b$ \\
\hline $\begin{array}{l}\text { Culm length }[\mathrm{cm}] \\
\text { p-value }\end{array}$ & $63.8 \pm 3.0$ & $\begin{array}{l}37.7 \pm 2.5 \\
<0.001\end{array}$ & $\begin{array}{l}39.7 \pm 2.9 \\
<0.001\end{array}$ & $61.2 \pm 4.5$ & $\begin{array}{l}38.4 \pm 2.8 \\
<0.001\end{array}$ & $68.3 \pm 4.1$ & $\begin{array}{l}41.9 \pm 2.6 \\
<0.001\end{array}$ \\
\hline $\begin{array}{l}\text { Spike length }[\mathrm{cm}] \\
\text { p-value }\end{array}$ & $8.4 \pm 0.89$ & $\begin{array}{l}8.1 \pm 0.55 \\
>0.05\end{array}$ & $\begin{array}{l}7.7 \pm 0.56 \\
>0.05\end{array}$ & $9.2 \pm 0.87$ & $\begin{array}{l}8.9 \pm 0.99 \\
>0.05\end{array}$ & $8.9 \pm 0.82$ & $\begin{array}{l}8.0 \pm 0.74 \\
>0.05\end{array}$ \\
\hline $\begin{array}{l}\text { Ratio length }(\text { spike }+ \text { awn)/spike } \\
\text { p-value }\end{array}$ & $2.5 \pm 0.21$ & $\begin{array}{l}1.3 \pm 0.18 \\
<0.001\end{array}$ & $\begin{array}{l}1.4 \pm 0.14 \\
<0.001\end{array}$ & $2.3 \pm 0.16$ & $\begin{array}{l}1.2 \pm 0.11 \\
<0.001\end{array}$ & $2.6 \pm 0.22$ & $\begin{array}{l}1.3 \pm 0.11 \\
<0.001\end{array}$ \\
\hline $\begin{array}{l}\text { Number of grains per spike } \\
\text { p-value }\end{array}$ & $20.8 \pm 1.7$ & $\begin{array}{l}19.5 \pm 1.7 \\
>0.05\end{array}$ & $\begin{array}{l}20.1 \pm 1.5 \\
>0.05\end{array}$ & $29.1 \pm 1.9$ & $\begin{array}{l}28.6 \pm 1.3 \\
>0.05\end{array}$ & $28.7 \pm 1.5$ & $\begin{array}{l}28.6 \pm 1.2 \\
>0.05\end{array}$ \\
\hline
\end{tabular}

Ten plants were analysed of each genotype. In each plant the tallest tiller has been measured. The table shows average \pm standard deviation. The p-value (unpaired Student's t-test) was obtained in comparisons between the mutant lines and the respective mother cultivar shown to the left of the mutant

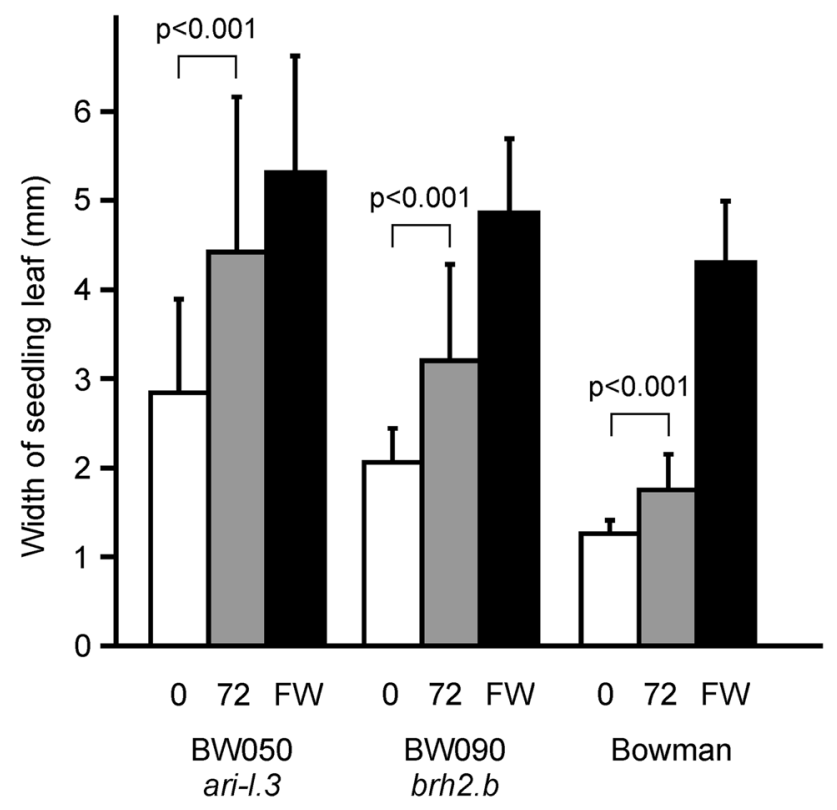

Fig. 2 Sensitivity to exogenously applied 24-epi-brassinolide as determined by a leaf-unrolling assay. Twenty barley seeds were germinated and grown in constant darkness until etiolated seedlings of approximately $15 \mathrm{~cm}$ were obtained. A two $\mathrm{cm}$ central leaf segment was cut from each leaf and submerged in $200 \mathrm{nM} 24$-epi-brassinolide. The width of each leaf was measured when newly cut (white bars show average, lines show standard deviation) and after $72 \mathrm{~h}$ (grey bars). The full width (FW, leaf segment forced open) was also measured (black bars). Both mutants and the wild type cultivar Bowman unroll as a response to exogenously added brassinolide, which indicate that they contain a functional brassinosteroid signaling pathway. The p-values were calculated from a paired Student's t-test

exogenously added brassinolide indicating no deficiencies in the brassinosteroid signalling pathway. Instead, our results suggest that the apparent brassinosteroid-deficient phenotype might be due to reduced brassinosteroid synthesis or increased brassinosteroid degradation since they behave like Bowman and brassinosteroid biosynthetic mutants, which respond to exogenous brassinolide in leaf-unrolling and leaf lamina inclination assays (Dockter et al. 2014).

The Brh2 locus has previously been mapped to barley chromosome 4H, $1.5 \mathrm{cM}$ proximal to Gsh3 (Takahashi et al. 1971). Analysis of near-isogenic lines BW050 (ari-l.3) and BW090 (brh2.b) provided further details on the chromosomal location of Brh2 (Druka et al. 2011). The introgression regions of BW050 (ari-l.3) and BW090 (brh2.b) are defined by SNP markers 2_1374 and 2_1332 on barley chromosome 4H (Druka et al. 2011). These markers correspond to positions $28.4 \mathrm{cM}$ (bp 21,432,445) and $77.31 \mathrm{cM}$ (bp 585,756,569) in the barley physical map (Mascher et al. 2017). The large genomic region of approximately $564 \mathrm{Mbp}$ contains 2342 high-confidential gene models (Mascher et al. 2017). Considering the fact that BW050 and BW090 have been generated through six recurrent backcrosses and that the introgression regions is still $564 \mathrm{Mbp}$ compared to the size of chromosome $4 \mathrm{H}$, which is approximately $650 \mathrm{Mbp}$, we excluded a mapping approach as an efficient method to identify the genetic identity of the Brh2 locus. Instead we employed a candidate gene approach to identify the gene deficient in $b r h 2$ and ari-l mutants. During a manual inspection of the annotations of the 2342 genes in the $564 \mathrm{Mbp}$ region we immediately noted the presence of two candidate genes of relevance for a short-culm phenotype; $H v D W F 4$ (HORVU4Hr1G065440) encoding a cytochrome P450 enzyme catalysing a hydroxylation at the $22-\mathrm{C}$ position of the steroid in the brassinosteroid biosynthetic pathway (Choe et al. 1998), as well as HvTUD1 (HORVU4Hr1G066070, located between bp 550,510,764-550,513,664 on chromosome $4 \mathrm{H}$ at $59.89 \mathrm{cM}$ (Mascher et al. 2017)) encoding a polypeptide which is $92 \%$ identical to OSTUD1 (Os03g13010) encoding a U-box E3 ubiquitin ligase in rice (Hu et al. 2013). Both DWF4 and TUDl are associated with dwarfism in plants (Choe et al. 1998; Hu et al. 2013). DNA sequencing of the HvDWF4 gene from BW050 (aril.3) and BW090 (brh2.b) revealed no mutations (Dockter 


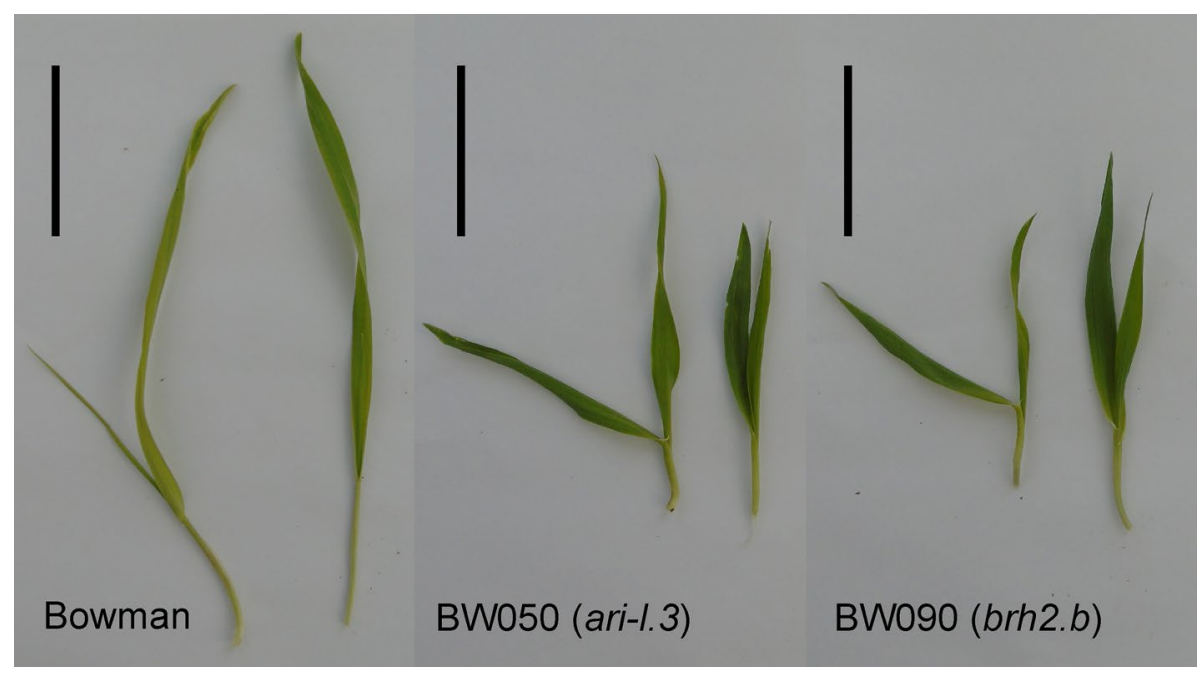

Fig. 3 Leaf lamina inclination assay performed on barley cultivar Bowman (wild type), BW050 (ari-l.3) and BW090 (brh2.b). The left plant in each photo was treated with 24-epi-brassinolide dissolved in $96 \%(\mathrm{v} / \mathrm{v})$ ethanol. The control plant to the right in each photo was treated with $96 \%$ ethanol. The wide angle between the first and

et al. 2014). In contrast, we found mutations in HvTUDl in BW050, BW090 and six of the seven ari-l mutant lines (Fig. 4). C-to-T substitutions were found in the three mutants ari-l.135, ari-l.145 and ari-l.214. In ari-l.135 this causes an exchange of Ser-382 to Phe in the armadillo-like fold of the HvTUD1 polypeptide. This Ser residue is modified to Leu in the rice mutant tudl-2 (Hu et al. 2013). Lines ari-l.145 and ari-l.214 carry identical nonsense mutations resulting in a truncated polypeptide of 111 amino-acid residues, compared to the full-length protein of 460 residues. No fragments of HvTUD1 could be amplified in brh2.b, ari-l.3, ari-l.132, aril.237, BW050 (ari-l.3) or BW090 (brh2.b) suggesting that these mutants carry deletions of the entire HvTUD1 gene. No mutation could be found in ari-l.257. Instead, mutant ari-l.257 and its mother cultivar Kristina showed three differences compared to the consensus sequence of cultivar Foma (Fig. 4); an A-to-C substitution 88 bp proximal to the ATG start codon, a silent C-to-T substitution in the coding region, and an insertion of a $\mathrm{G} 86 \mathrm{bp}$ downstream of the TGA stop codon. Since the differences are found in both ari-l.257 and Kristina, we do not expect them to affect the HvTUD1 gene product in a negative way. Thus, the mutation causing the semi-dwarf phenotype in ari-l.257 is in an unknown gene different from HVTUDl and the mutant should therefore be named ari-257. We have previously identified genes deficient in historic mutants obtained from various seedbank collections and occasionally experienced that accessions have been mixed over the decades (Mueller et al. 2012; Zakhrabekova et al. 2012, 2015. The identification of severe mutations in HVTUD1 in 9 out of 10 available second leaf in each plant treated with brassinosteroid compared to the small angle in the control plants just treated with ethanol demonstrates that Bowman, BW050 (ari-l.3) and BW090 (brh2.b) can respond to exogenously added brassinosteroid and suggests that they have a functional brassinosteroid signaling pathway. Black bar; $5 \mathrm{~cm}$

accessions strongly support $H v T U D 1$ as the gene responsible for the short-culm phenotype of the brh2 and ari-l mutants.

\section{Discussion}

It was recently found that the TUDl gene product in rice encodes a U-box E3 ubiquitin ligase (Hu et al. 2013). Five allelic rice $t u d l$ mutants showed a semi-dwarf phenotype similar to rice $d l$ mutants deficient in the gene encoding the $\mathrm{G} \alpha$ subunit of the heterotrimeric $\mathrm{G}$ protein. Mutants in $T U D 1$ and $D 1$ are characterized by a short second internode, erect leaves and photomorphogenic growth in darkness. Hu et al. (Hu et al. 2013) showed in rice that the Ga subunit encoded by $D 1$ physically interacts with the E3 ubiquitin ligase encoded by TUD1 and suggested that TUD1 functions as an activator of brassinosteroid signalling.

Ubiquitination is a post-translational modification of proteins and one of the most prominent mechanisms that regulates protein degradation to modulate protein levels in eukaryotic cells (Ciechanover 2005). This also includes proteins involved in signalling and metabolism of plant hormones such as auxin, gibberellic acid, jasmonic acid, ethylene, abscisic acid and brassinosteroids (Hu et al. 2013; Vierstra 2009). Ubiquitin is a polypeptide of 76 amino-acid residues. It becomes covalently attached to target proteins through the action of three enzymes; an E1 ubiquitin-activating enzyme, an E2 ubiquitin-conjugating enzyme and an E3 ubiquitin ligase (Bae and Kim 2014). The target specificity is determined by the E3 ubiquitin ligases, which binds to their specific substrate proteins. There are many genes 
Fig. 4 The barley HvTUD1 gene as determined in the cultivar Foma encoding a U-box E3 ubiquitin ligase. The genomic DNA sequence shown in the figure consists of only one exon. Below the DNA sequence is the polypeptide sequence of 460 amino-acid residues. The postulated U-box domain and a domain with an armadillo-like fold are marked in light grey (amino-acid residues 65-139) and dark grey (171-440), respectively (Groves and Barford 1999; Hu et al. 2013; Vogelmann et al. 2014). Identical amino-acid residues between barley and rice TUD1 are marked in bold and nonidentical residues are marked in italic. The ari-l.145 and ari-l.214 mutants have identical nonsense mutations resulting in a truncated polypeptide of 111 amino-acid residues. The ari-l.135 point mutation results in exchange of Ser-382 to Phe in the armadillo-like fold domain. The mutants brh2.b, ari-l.3, ari-l.132 and ari-l.237 are probably large deletions since no fragments of $H v T U D 1$ could be amplified by PCR. No mutation could be found in ari-l.257. Three SNPs could be detected in ari-l.257 and the mother cultivar Kristina. The consensus sequence shown in the figure is identical to that of MLOC_79322 (International Barley Genome Sequencing et al. 2012)

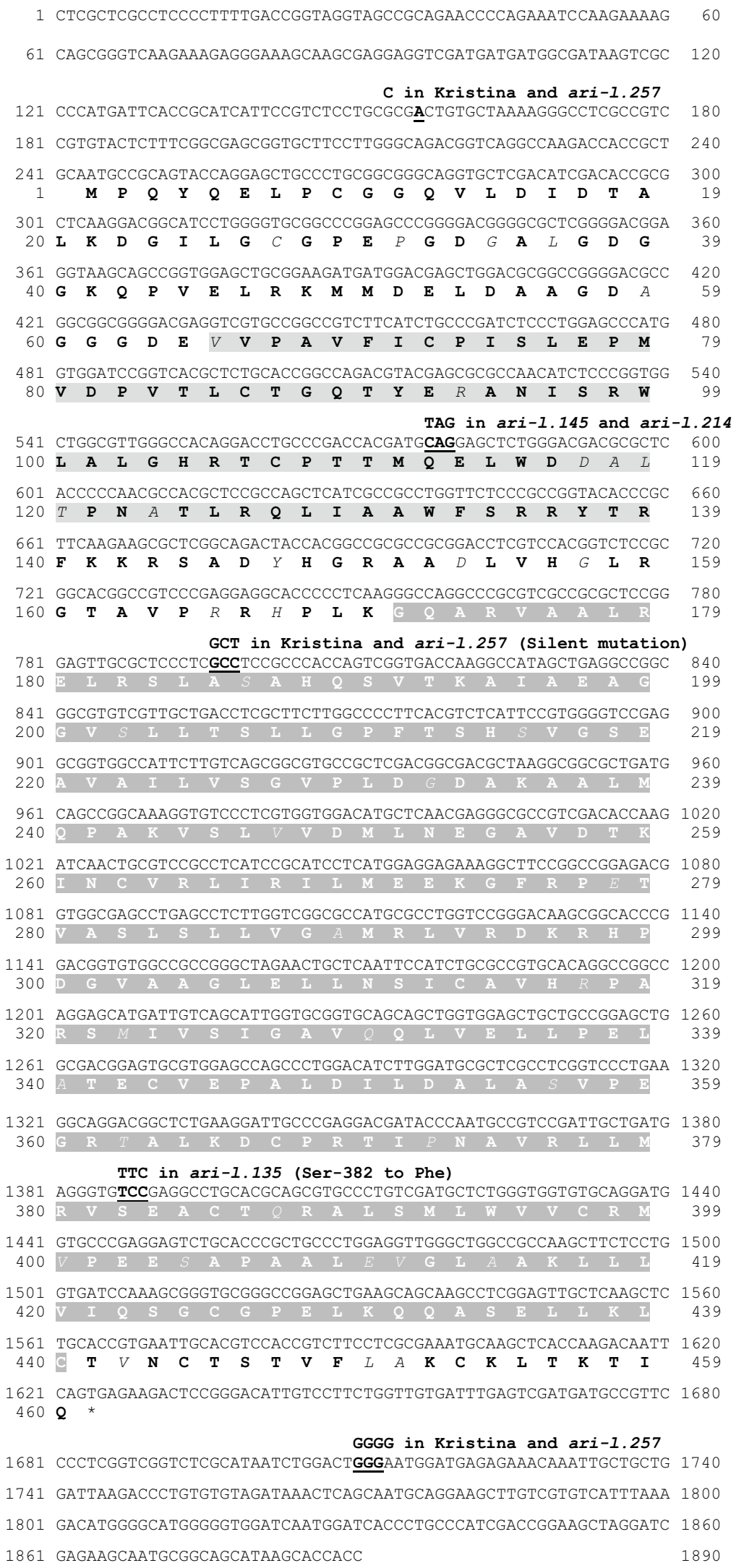


encoding E3 ubiquitin ligases in plant genomes (Du et al. 2009; Smalle and Vierstra 2004). In contrast, there are only a few genes encoding E1 ubiquitin-activating enzymes and E2 ubiquitin-conjugating enzymes. The E3 ubiquitin ligases are divided into three classes depending on the presence of one of three protein domains; HECT, RING or U-box (Ardley and Robinson 2005; Deshaies and Joazeiro 2009; Rotin and Kumar 2009). The rice TUD1 and the barley Brh2 gene products belong to the U-box class of E3 ubiquitin ligases. There are 64 and 77 genes encoding U-box E3 ubiquitin ligases in Arabidopsis and rice, respectively (Yee and Goring 2009; Zeng et al. 2008). The barley Brh2 polypeptide shows $92 \%$ identical residues to that of rice TUD1 and the two genes are located in a syntenic region comparing barley chromosome $4 \mathrm{H}$ and rice chromosome 3 . The barley and rice genomes show no other gene products that are more than $35 \%$ identical to Brh2 or TUD1. Thus, we strongly believe that Brh2 and TUD1 are orthologous genes.

In short-culm rice TUD1 mutants as well as in short-culm barley brh 2 and ari-l mutants reported in this study, a functional E3 ubiquitin ligase is absent as a consequence of the mutations. Since the function of the ubiquitin machinery is to degrade proteins, the TUD1 encoded E3 ubiquitin ligase probably initiate the removal of a factor that represses elongation in a wild type plant. Thus, absence of a functional E3 ubiquitin ligase in a tudl, brh2 or ari-l mutant results in a semi-dwarf phenotype because the repressor of elongation is not degraded. Therefore, the TUD1/Brh2/Ari-l encoded E3 ubiquitin ligase should be regarded as an activator of plant elongation. The physical interaction between TUDl encoded E3 ubiquitin ligase and the $\mathrm{G} \alpha$ subunit of a heterotrimeric $\mathrm{G}$ protein in rice (Hu et al. 2013) suggests that the Go subunit is the degradation target of the TUD1 encoded E3 ubiquitin ligase. However, the $\mathrm{G} \alpha$ subunit functions as an activator of elongation rather than a repressor since mutations in the gene of $\mathrm{G} \alpha$ in rice and barley cause a short-culm phenotype (Braumann et al. 2017; Wang et al. 2006). Therefore, further analyses of the relationship between the TUD1 encoded E3 ubiquitin ligase and the $\mathrm{G} \alpha$ subunit are required.

The rice tudl-2 mutant showed normal sensitivity to gibberellic acid and cytokinin but less sensitivity to exogenously applied brassinosteroid (Hu et al. 2013). It was suggested that the TUD1 encoded E3 ubiquitin ligase participates in a second brassinosteroid signalling pathway in rice, which is independent of the BRI1 brassinosteroid receptor (Hu et al. 2013). In the present study we found that the apparent brassinosteroid deficient phenotype of barley brh2 and ari-l mutants (Fig. 1) is not caused by deficient brassinosteroid signalling; in leaf-unrolling and leaf lamina inclination bioassays we did detect a clear response to exogenously added 24-epi-brassinolide. In order to provide an explanation to the apparent brassinosteroid deficient phenotype of barley brh2 and ari-l mutants, we suggest that
TUD1/Brh2/Ari-l might be related to brassinosteroid synthesis or degradation rather than signalling, since mutants deficient in brassinosteroid biosynthesis or signalling are phenotypically very similar in barley, if not indistinguishable (Dockter et al. 2014). We also want to point out that our idea about a brassinosteroid deficient ideotype (Dockter et al. 2014) could be wrong in the sense that also mutations in non-brassinosteroid related genes might cause a phenotype that we interpret as brassinosteroid deficient. We suggest that further analyses are required in order to decipher the molecular mechanisms underlying the short-culm phenotype of $t u d l, b r h 2$ and ari-l deficient mutants and the relation of this gene to brassinosteroid signalling and metabolism, as well as heterotrimeric $\mathrm{G}$ proteins.

Acknowledgements We thank Udda Lundqvist for valuable discussions and the Nordic Genetic Resource Center for providing seeds. This work was supported by the Carlsberg Foundation, the Green Development and Demonstration Programme (GUDP, the Ministry of Environment and Food, Denmark, 34009-12-0522), Deutsche Forschungsgemeinschaft (Germany, DO1482/1-1), the C.F. Lundström Foundation at the Royal Swedish Academy of Agriculture and Forestry, the NilssonEhle Foundation at the Royal Physiographic Society in Lund, and the Crafoord Foundation.

Author contributions IB, CD and $\mathrm{MH}$ designed research. WU, AP and $\mathrm{SZ}$ performed experimental work. MH wrote the paper.

Open Access This article is distributed under the terms of the Creative Commons Attribution 4.0 International License (http://creativeco mmons.org/licenses/by/4.0/), which permits unrestricted use, distribution, and reproduction in any medium, provided you give appropriate credit to the original author(s) and the source, provide a link to the Creative Commons license, and indicate if changes were made.

\section{References}

Ahloowalia BS, Maluszynski M, Nichterlein K (2004) Global impact of mutation-derived varieties. Euphytica 135:187-204

Ardley HC, Robinson PA (2005) E3 ubiquitin ligases. Essays Biochem 41:15-30

Assmann SM (2002) Heterotrimeric and unconventional GTP binding proteins in plant cell signaling. Plant Cell 14 Suppl:S355-S373

Bae H, Kim WT (2014) Classification and interaction modes of 40 rice E2 ubiquitin-conjugating enzymes with 17 rice ARM-U-box E3 ubiquitin ligases. Biochem Biophys Res Commun 444:575-580

Bouma J (1967) New varieties of spring barley, "Diamant" in Czechoslovakia. Induzierte Mutationen und ihre Nutzung, Erwin Baur Gedächtnisvorlesung IV, 1966, vol 2. Abh Dt Akad Wiss Berl Akademie-Verlag, Berlin

Braumann I, Dockter C, Beier S, Himmelbach A, Lok F, Lundqvist L, Skadhauge B, Stein N, Zakhrabekova S, Zhou R, Hansson M (2017) Mutations in the gene of the Ga subunit of the heterotrimeric $\mathrm{G}$ protein are the cause for the brachyticl semi-dwarf phenotype in barley and applicable for practical breeding. Hereditas 155:10

Choe S, Dilkes BP, Fujioka S, Takatsuto S, Sakurai A, Feldmann KA (1998) The DWF4 gene of Arabidopsis encodes a cytochrome 
P450 that mediates multiple $22 \alpha$-hydroxylation steps in brassinosteroid biosynthesis. Plant Cell 10:231-243

Chono M, Honda I, Zeniya H, Yoneyama K, Saisho D, Takeda K, Takatsuto S, Hoshino T, Watanabe Y (2003) A semidwarf phenotype of barley uzu results from a nucleotide substitution in the gene encoding a putative brassinosteroid receptor. Plant Physiol 133:1209-1219

Ciechanover A (2005) Intracellular protein degradation: from a vague idea thru the lysosome and the ubiquitin-proteasome system and onto human diseases and drug targeting. Cell Death Differ 12:1178-1190

Dahleen LS, Vander Wal LJ, Franckowiak JD (2005) Characterization and molecular mapping of genes determining semidwarfism in barley. J Hered 96:654-662

Deshaies RJ, Joazeiro CA (2009) RING domain E3 ubiquitin ligases. Annu Rev Biochem 78:399-434

Dockter C, Gruszka D, Braumann I, Druka A, Druka I, Franckowiak J, Gough SP, Janeczko A, Kurowska M, Lundqvist J, Lundqvist U, Marzec M, Matyszczak I, Muller AH, Oklestkova J, Schulz B, Zakhrabekova S, Hansson M (2014) Induced variations in brassinosteroid genes define barley height and sturdiness, and expand the green revolution genetic toolkit. Plant Physiol 166:1912-1927

Druka A, Franckowiak J, Lundqvist U, Bonar N, Alexander J, Houston K, Radovic S, Shahinnia F, Vendramin V, Morgante M, Stein N, Waugh R (2011) Genetic dissection of barley morphology and development. Plant Physiol 155:617-627

Du Z, Zhou X, Li L, Su Z (2009) plantsUPS: a database of plants' Ubiquitin Proteasome System. BMC Genom 10:227

Foster BP (2001) Mutation genetics of salt tolerance in barley: an assessment of Golden Promise and other semi-dwarf mutants. Euphytica 120:317-328

Fujioka S, Noguchi T, Takatsuto S, Yoshida S (1998) Activity of brassinosteroids in the dwarf rice lamina inclination bioassays. Phytochemistry 49:1841-1848

Groves MR, Barford D (1999) Topological characteristics of helical repeat proteins. Curr Opin Struct Biol 9:383-389

Gruszka D, Szarejko I, Maluszynski M (2011) New allele of HvBRII gene encoding brassinosteroid receptor in barley. J Appl Genet $52: 257-268$

Haahr V, von Wettstein D (1976) Studies of an induced, high-yielding dwarf-mutant of spring barley. In: Gaul H (ed) Barley Genetics III, Proceedings 3rd international barley genetics symposium, Garching, 1975. Verlag Karl Thiemig, Munich

Hellewell KB, Rasmusson DC, Gallo-Meagher M (2000) Enhancing yield of semidwarf barley. Crop Sci 40:352-358

Honda I, Zeniya H, Yoneyama K, Chono M, Kaneko S, Watanabe Y (2003) Uzu mutation in barley (Hordeum vulgare L.) reduces the leaf unrolling response to brassinolide. Biosci Biotechnol Biochem 67:1194-1197

Hong Z, Ueguchi-Tanaka M, Umemura K, Uozu S, Fujioka S, Takatsuto S, Yoshida S, Ashikari M, Kitano H, Matsuoka M (2003) A rice brassinosteroid-deficient mutants, ebisu $d w a r f(d 2)$, is caused by a loss of function of a new member of cytochrome P450. Plant Cell 15:2900-2910

Houston K, McKim SM, Comadran J, Bonar N, Druka I, Uzrek N, Cirillo E, Guzy-Wrobelska J, Collins NC, Halpin C, Hansson M, Dockter C, Druka A, Waugh R (2013) Variation in the interaction between alleles of HvAPETALA2 and microRNA172 determines the density of grains on the barley inflorescence. Proc Natl Acad Sci USA 110:16675-16680

Hu X, Qian Q, Xu T, Zhang Y, Dong G, Gao T, Xie Q, Xue Y (2013) The U-box E3 ubiquitin ligase TUD1 functions with a heterotrimeric $\mathrm{G} \alpha$ subunit to regulate brassinosteroid-mediated growth in rice. PLoS Genet 9:e1003391

Ito A, Yasuda A, Yamaoka K, Ueda M, Nakayama A, Takatsuto S, Honda I (2017) Brachytic 1 of barley (Hordeum vulgare L.) encodes the $\alpha$ subunit of heterotrimeric G protein. J Plant Physiol 213:209-215

Johnston CA, Taylor JP, Gao Y, Kimple AJ, Grigston JC, Chen JG, Siderovski DP, Jones AM, Willard FS (2007) GTPase acceleration as the rate-limiting step in Arabidopsis $\mathrm{G}$ protein-coupled sugar signaling. Proc Natl Acad Sci USA 104:17317-17322

Kato C, Mizutani T, Tamaki H, Kumagai H, Kamiya T, Hirobe A, Fujisawa Y, Kato H, Iwasaki Y (2004) Characterization of heterotrimeric $\mathrm{G}$ protein complexes in rice plasma membrane. Plant J 38:320-331

Kucera J, Lundqvist U, Gustafsson $\AA$ (1975) Induction of breviaristatum mutants in barley. Hereditas 80:263-278

Mascher M, Gundlach H, Himmelbach A, Beier S, Twardziok SO, Wicker T, Radchuk V, Dockter C, Hedley PE, Russell J, Bayer M, Ramsay L, Liu H, Haberer G, Zhang XQ, Zhang Q, Barrero RA, Li L, Taudien S, Groth M, Felder M, Hastie A, Simkova H, Stankova H, Vrana J, Chan S, Munoz-Amatriain M, Ounit R, Wanamaker S, Bolser D, Colmsee C, Schmutzer T, Aliyeva-Schnorr L, Grasso S, Tanskanen J, Chailyan A, Sampath D, Heavens D, Clissold L, Cao S, Chapman B, Dai F, Han Y, Li H, Li X, Lin C, McCooke JK, Tan C, Wang P, Wang S, Yin S, Zhou G, Poland JA, Bellgard MI, Borisjuk L, Houben A, Dolezel J, Ayling S, Lonardi S, Kersey P, Langridge P, Muehlbauer GJ, Clark MD, Caccamo M, Schulman AH, Mayer KFX, Platzer M, Close TJ, Scholz U, Hansson M, Zhang G, Braumann I, Spannagl M, Li C, Waugh R, Stein N (2017) A chromosome conformation capture ordered sequence of the barley genome. Nature 544:427-433

Mueller AH, Dockter C, Gough SP, Lundqvist U, von Wettstein D, Hansson M (2012) Characterization of mutations in barley $f c h 2$ encoding chlorophyllide $a$ oxygenase. Plant Cell Physiol 53:1232-1246

Oki K, Inaba N, Kitagawa K, Fujioka S, Kitano H, Fujisawa Y, Kato $H$, Iwasaki Y (2009) Function of the $\alpha$ subunit of rice heterotrimeric $\mathrm{G}$ protein in brassinosteroid signaling. Plant Cell Physiol 50:161-172

Porter JR, Semenov MA (2005) Crop responses to climatic variation. Philos Trans R Soc Lond B Biol Sci 360:2021-2035

Rotin D, Kumar S (2009) Physiological functions of the HECT family of ubiquitin ligases. Nat Rev Mol Cell Biol 10:398-409

Saisho D, Tanno K, Chono M, Honda I, Kitano H, Takeda K (2004) Spontaneous brassinolide-insensitive barley mutants " $и z u$ " adapted to East Asia. Breed Sci 54:409-416

IBGS (2012) A physical, genetic and functional sequence assembly of the barley genome. Nature 491:711-716

Skov Kristensen P, Dockter C, Lundqvist U, Lu Q, Gregersen L, Thordal-Christensen P, Hansson M (2016) Genetic mapping of the barley lodging resistance locus Erectoides- $k$. Plant Breed 135:420-428

Smalle J, Vierstra RD (2004) The ubiquitin 26S proteasome proteolytic pathway. Annu Rev Plant Biol 55:555-590

Takahashi R (1955) The origin and evolution of cultivated barley. In: Demerec M (ed) Advances in genetics, vol 7. Academic Press, New York, pp 227-266

Takahashi R, Hayashi J, Moriya I (1971) Linkage studies in barley. Barley Genet Newsl 1:51-58

Temple BR, Jones AM (2007) The plant heterotrimeric G-protein complex. Annu Rev Plant Biol 58:249-266

Tsuchiya T (1962) Radiation breeding in two-rowed barley. Seiken Ziho 14:21-34

Urano D, Chen JG, Botella JR, Jones AM (2013) Heterotrimeric G protein signalling in the plant kingdom. Open Biol 3:120186

Utsunomiya Y, Samejima C, Takayanagi Y, Izawa Y, Yoshida T, Sawada Y, Fujisawa Y, Kato H, Iwasaki Y (2011) Suppression of the rice heterotrimeric $\mathrm{G}$ protein beta-subunit gene, $R G B 1$, causes dwarfism and browning of internodes and lamina joint regions. Plant J 67:907-916 
Vestergaard E, Holme Hansen HH, Engel G (1949) Planteavlen paa Lolland-Falster 1948. Central-trykkeriet, Nykøbing

Vierstra RD (2009) The ubiquitin-26S proteasome system at the nexus of plant biology. Nat Rev Mol Cell Biol 10:385-397

Vogelmann K, Subert C, Danzberger N, Drechsel G, Bergler J, Kotur T, Burmester T, Hoth S (2014) Plasma membrane-association of SAUL1-type plant U-box armadillo repeat proteins is conserved in land plants. Front Plant Sci 5:37

Wang L, Xu YY, Ma QB, Li D, Xu ZH, Chong K (2006) Heterotrimeric $\mathrm{G}$ protein $\alpha$ subunit is involved in rice brassinosteroid response. Cell Res 16:916-922

Wendt T, Holme I, Dockter C, Preu $\beta$ A, Thomas W, Druka A, Waugh $\mathrm{R}$, Hansson M, Braumann I (2016) HvDepl is a positive regulator of culm elongation and grain size in barley and impacts yield in an environment-dependent manner. PLoS ONE 11:e0168924

Xu Y, Jia Q, Zhou G, Zhang XQ, Angessa T, Broughton S, Yan G, Zhang W, Li C (2017) Characterization of the $s d w 1$ semi-dwarf gene in barley. BMC Plant Biol 17:11
Yee D, Goring DR (2009) The diversity of plant U-box E3 ubiquitin ligases: from upstream activators to downstream target substrates. J Exp Bot 60:1109-1121

Zakhrabekova S, Gough SP, Braumann I, Muller AH, Lundqvist J, Ahmann K, Dockter C, Matyszczak I, Kurowska M, Druka A, Waugh R, Graner A, Stein N, Steuernagel B, Lundqvist U, Hansson M (2012) Induced mutations in circadian clock regulator Mat- $a$ facilitated short-season adaptation and range extension in cultivated barley. Proc Natl Acad Sci USA 109:4326-4331

Zakhrabekova S, Dockter C, Ahmann K, Braumann I, Gough SP, Wendt T, Lundqvist U, Mascher M, Stein N, Hansson M (2015) Genetic linkage facilitates cloning of Ert- $m$ regulating plant architecture in barley and identified a strong candidate of Ant 1 involved in anthocyanin biosynthesis. Plant Mol Biol 88:609-626

Zeng LR, Park CH, Venu RC, Gough J, Wang GL (2008) Classification, expression pattern, and E3 ligase activity assay of rice U-boxcontaining proteins. Mol Plant 1:800-815 